\title{
SCHOPENHAUER Y LA FORMALIZACIÓN DE LA MELANCOLÍA EN LAS LETRAS ESPAÑOLAS DEL NOVECIENTOS
}

\author{
Ángel L. PRIETO DE PAULA \\ Universidad de Alicante
}

\section{Introducción}

Es sabido que el pensamiento filosófico, en cualquier época que queramos considerar, ha ido de la mano de la creación literaria, tirando de ella o arrastrado por ella. Parece ésta una verdad de Perogrullo; pero no lo es del todo, porque en determinados países va tan por delante la filosofía respecto a la literatura, o al revés, que la tracción a que una somete a la otra está al borde de producir una desvinculación de hecho.

Apenas hace falta acudir al caso de España, en que tan retardadas han ido la filosofía y la ciencia con respecto a la literatura y las artes. De ese retardo - algunos, más extremados, llegan a hablar de ausencia efectiva de pensamiento filosófico-, o de la negación del mismo, han quedado huellas abundantes en la disputa intelectual que se inició en 1782 cuando Masson de Morvilliers, en el artículo "Espagne" con que contribuía a la Encyclopédie méthodique, formulaba su retórica pregunta sobre la insignificancia de la labor española en beneficio de Europa y de la Humanidad ("Quoi on doit à l'Espagne?"). En contra, y en algún caso a favor, del juicio implícito en la pregunta se pronunciaron enseguida diversos polemistas (Cavanilles, Denina, Forner, Cañuelo, Iriarte...). Casi un siglo después acorrería a su impugnación el entonces jovencísimo Menéndez Pelayo, quien, a partir de una consideración tangencial del krausista Gumersindo de Azcárate en 1876 en la Revista España (Azcárate, 1877), sobre la esterilizadora incidencia de la falta de libertad de conciencia en el desarrollo científico español, inició su particular defensa de la ciencia y la filosofía españolas, tal como queda expuesto en sus entregas a la 
Revista Europa, recopiladas en 1876 con el título de La ciencia española. Independientemente de las razones con que unos y otros comparecieron en la palestra, de puertas afuera la impresión más común y acaso injusta es la que concuerda con el cáustico Unamuno, quien tras confesarse inicialmente escéptico respecto a la existencia de una filosofía española, afirma que la obra de Menéndez Pelayo, contrariamente a lo que se proponía, lo afianzó en su idea de que el pueblo español se ha mostrado siempre retuso a toda comprensión verdaderamente filosófica (Abellán, 1979, pp. 51-71; García Camarero, 1970).

El problema antedicho no ha impedido en general una conexión sostenida, con distintos grados de evidencia, entre el pensamiento filosófico español y la creación artística, específicamente literaria. Sólo en los albores del siglo XX parece haberse alterado la correspondencia entre filosofía y literatura, y no porque se hayan dado la espalda por incoincidencia de sus respectivos intereses, sino porque la sucesividad regular del pensamiento filosófico, que encadena diacrónicamente unos tramos con otros generados a partir del agotamiento o la recusación de los anteriores, dio paso a un sistema de solapamiento de corrientes, que se presentaban en frecuente simultaneidad, acrecida por el hecho de que la actividad editorial y las traducciones favorecían una casi inmediata filtración de aquéllas.

En los años finales del ochocientos, cuando la generación realista-naturalista comenzó a manifestar síntomas de agotamiento creativo y la finisecular se aprestaba a su irrupción literaria, que se produciría centralizadamente entre 1895 (Unamuno, En torno al casticismo) y 1902 (J. Martínez Ruiz, La voluntad; Baroja, Camino de perfección; Unamuno, Amor y pedagogía; Valle-Inclán, Sonata de otoño), estaban actuando en la constitución del universo filosófico de los jóvenes escritores, e interfiriéndose por ósmosis, diversos cursos de pensamiento; entre otros, la liquidación del optimismo metafísico por parte de Schopenhauer y su teoría de la voluntad; el racionalismo armónico del krausopositivismo orientado pedagógicamente a la creación de un hombre nuevo; el filantropismo cristiano sin soporte dogmático de Tolstoi, asentado en la compasión, la misma que niega Nietzsche con su teoría del superhombre o del "ultrahombre"; y la angustia y el antisistematismo de Kierkegaard —otro antihegeliano como Schopenhauer (Maceiras, 1985)-, cuyo individualismo atormentado se radica en el centro de la sensibilidad religiosa de Unamuno. Ello por no hablar del entonces naciente pragmatismo religioso, que en oposición al absolutismo hegeliano parece haber diseñado el campo relativista de la modernidad.

\section{Límites de la razón, acefalía del mundo}

En el fondo, el aludido cruce de corrientes tiene que ver con el cierre de expectativas filosóficas, bien visible desde la kantiana Crítica de la razón pura, que venía a reconocer lo ilusorio de una metafísica teórica y la imposibilidad de que el discurrir especulativo pudiera saltar las bardas de sus propios límites y demostrar cualquiera 
de los principios metafísicos relativos a Dios (fundamentalmente su existencia), la sustancia universal y el alma (específicamente su inmortalidad). La multiplicación de derroteros filosóficos postkantianos se explica por un afán de vislumbrar una salida a la situación heredada, como el ciego que, perdido en un laberinto, manotea en todas las direcciones, prueba regresiones y avances, se dirige a un lugar y a su contrario, inicia trayectos que no concluye. Un gigante poético como Leopardi y un metafísico como Schopenhauer, en la primera generación, un músico de grandiosidad épica como Wagner y un visionario como Nietzsche, en la segunda, y hasta un heredero de Schopenhauer tan evidente como Freud, ya en una tercera generación, son ejemplos de la retracción de la razón, incapacitada para ahormar y reconducir el caos de la existencia a un orden lógico, cabe decir sustentarla en el logos, tarea que se revela, cada vez más nítidamente, fuera del alcance humano ${ }^{1}$.

Sin embargo, la retracción de la razón no se produce sin coste alguno para quienes asisten a ella, pues los embates del sinsentido ponen a prueba el orgullo humano; digo el orgullo, y no la dignidad, ya que ésta puede asentarse en la precariedad o miseria de nuestro ser. En unas "Reflexiones sobre la lírica", a propósito de Colección (1924), de José Moreno Villa, Antonio Machado veía este proceso, referido fundamentalmente al arte simbolista, de la siguiente manera:

Los simbolistas - poetas de antes de ayer-, en cuanto mostraron un cierto acuerdo consigo mismos, una cierta congruencia entre sus propósitos y sus realizaciones, dejaban ver cuál era esa fe, esas últimas creencias, esa metafísica que estaba en el fondo de su lírica. Llevaban muy marcado el acento de su tiempo. Hijos de la segunda mitad del siglo que había puesto al sol las raíces del ente de razón cartesiano, hubieran definido al hombre como un ser sensible sentimental, volente o ciegamente dinámico, y el [sic] poeta como un solitario, atento a su melodía interior. La inteligencia había perdido - ipara siempre? - su posición teórica. En el principio era la acción - ¿no fue éste el dogma del siglo? - y la inteligencia, mero y tardío - ipor qué no superfluo?- accidente vital, sólo podía aspirar a un rango inferior, de instrumento pragmático. Los poetas habían de desdeñarla. Esta fe agnóstica creó un arte de ciegos músicos. La pintura misma —el impresionismo- es pintura de ciegos que pretenden palpar la luz. La poesía declara la guerra a lo inteligible y aspira a la expresión pura de lo subconsciente, apelando a las potencias oscuras, a las raíces más soterrañas del ser. De la musique avant toute chose, había dicho Verlaine. Pero esta música de Verlaine no era la música de Mozart, que tenía aún la claridad, la gracia y la alegría del mundo leibniziano, todo él iluminado y vidente, sino la música de su tiempo, la música de Wagner, el poema sonoro de la total opacidad del ser, cuya letra era la metafísica de Schopenhauer (A. Machado, III, p. 1655).

$\mathrm{Y}$ es que, dejando a un lado lo que las precedentes afirmaciones deban a las reticencias con que Machado observaba el arte nuevo - en el tiempo en que su

1 Esta observación requeriría una exposición más demorada y puntillosa. Valga ahora especificar tan sólo que aparece una nueva definición conceptual de "razón": una razón instrumental circunscrita a los límites de la racionalidad científica, con el consiguiente abandono a la "irracionalidad", cuando no al olvido deliberado, de los grandes temas de la metafísica tradicional. 
admirado Ortega publicaba La deshumanización del arte-, hay en ellas un reconocimiento del fracaso de la inteligencia que el poeta conecta con las tendencias artísticas de las que Moreno Villa eran tan claro representante ${ }^{2}$.

Estamos tratando, en suma, de un debilitamiento del pulso de la racionalidad que la filosofía moderna había ido manifestando desde Kant o, en un orden cerradamente existencial, desde Rousseau. La "Profesión de fe del vicario saboyano", incluida en el Émile, expone tanto la concepción religiosa rousseauniana, profundamente natural y refractaria a leyes de religiones positivas, como el anonadamiento frente lo incognoscible y la genuflexión de la inteligencia ante las razones del corazón. En el centro de nuestro universo, el lugar que dejaba libre la racionalidad fue ocupado por "una potencia mística — sentimiento, voluntad, vitalidad, acción" (A. Machado, III, p. 1229).

Es así como se emprende el camino del irracionalismo - cercenamiento del pensar metafísico- en el que se instalará prolongadamente el quehacer filosófico. Este camino estaba previsto en el pensamiento kantiano, cuyas consecuencias tal como las percibe Andrés Hurtado, el protagonista de la novela de Baroja El árbol de la ciencia (1911) - son terribles, por el sometimiento de todo al encadenamiento de causas y efectos y por la propia negación de la idea de causa primera. El pensador antiidealista que es Schopenhauer, autodeclarado el "verdadero" continuador de Kant (algo que ocurrió con otros varios filósofos, que ni siquiera llegaron a agotar las posibilidades del sistema), se empecinaría en ingresar en el territorio espantable ante cuyo vislumbre se había detenido Kant. Por una parte disiente, según veremos, de la tradición filosófica occidental; pero por otra bebe en la fuente del pensamiento kantiano, retrocediendo hasta el punto en que aún no había aparecido la que él consideraba caterva de "filosofastros" académicos, y por supuesto el "aberrante" Hegel, su particular bestia negra ${ }^{3}$. Sin embargo, resulta bastante evidente que el Kant de Schopenhauer no es, inocentemente, Kant; y que el idealismo kantiano llega en Schopenhauer a un punto de inflexión a partir del cual el derrotero filosófico conduce directamente al irracionalismo de la segunda mitad del siglo

2 El peso que el schopenhauerismo tuvo en la constitución de la estética finisecular española no será valorado del todo sin tener en consideración la incidencia previa que en Rodenbach, Verhaeren, Maeterlinck y otros simbolistas belgas, de extraordinario influjo en los simbolistas españoles, tuvo la filosofía de Schopenhauer, según estudia Christian Berg (en Henry, 1989, pp. 119-34).

3 Claro que, con independencia de la oposición estrictamente filosófica entre su pensamiento y el hegeliano, no puede desatenderse la influencia que tuvieron sus avatares biográficos en las descalificaciones destempladas y frecuentes de que hizo objeto a Hegel, a los hegelianos, a la filosofía académica, a los profesores universitarios de filosofía y, en general, a los filósofos más aplaudidos de su tiempo, que se habrían conjurado - la conjura de los criados contra los señores-para silenciar su producción filosófica. Parte principal de tales avatares biográficos es el fracaso que vivió cuando en 1820, un año después de publicada su obra magna, El mundo como voluntad y representación, trabajó como profesor en la Universidad de Berlín sin conseguir que sus lecciones atrajeran a los alumnos, arracimados en torno a Hegel, recién incorporado a la misma, donde comenzaba a exponer su sistema con extraordinario éxito y a conformar la legión de hegelianos que no mucho más tarde habría de escindirse. 
XIX. En la filosofía kantiana el razonamiento metafísico queda malherido, dado que la razón carece de fuerza para salvar las limitaciones que la cercenan; pero, alicaída como está, aún es ella, la razón, el elemento sustentante de la realidad. Las bases kantianas a las que retorna Schopenhauer le sirven, en cierto sentido al menos, de depósito en el que se pertrecha para disponer desde allí el avance que arrasaría los débiles tabiques que había mantenido en pie el filósofo de Königsberg: "C'est pourtant Schopenhauer et nul autre qui a doté de radicalisme la révolution anthropologique amorcée par Kant. Ce dernier avait bien exclu l'homme de la communication directe avec l'Être mais il a rétabli ensuite l'ordre ancien. Seul Schopenhauer a, le premier, méthodiquement exploité toutes les conséquences de cette exclusion. Il a fixé et dessiné le nouveau destin de l'homme, avec sa laïcisation impitoyable, son irrationalisme malheureux, son scientisme antimatérialiste" (Henry, 1989, p. 12). En Los complementarios, Antonio Machado habla de acefalia del mundo para expresar este punto terminal: "En Schopenhauer, el mundo alcanza la máxima opacidad, es todo él ceguera, acefalía, impulso ciego" (A. Machado, III, pp. 1196-7); o:

La realidad es una potencia ciega, acéfala; poco podremos con fundamento decir de ella, por cuanto ella es lo primero, lo elemental e indefinible, lo creador del mundo de la representación, del sueño búdico en que vivimos sumergidos. Nuestra representación no podrá servirnos - si pensamos lógicamente - para penetrar en lo real. Nuestra coincidencia con lo real no puede expresarse en términos de conciencia. Ser es querer, ser parte de la voluntad cósmica. La filosofía de Schopenhauer nos llevará lógicamente a suponer la divergencia y heterogeneidad esencial entre el pensar y el querer, entre realidad y apariencia, entre fenómeno y noúmeno. Un paso más y el hombre se sentirá desintegrado del mundo real, con las raíces al aire y tanto más sumergido en un vano sueño, cuanto mayores sean sus hábitos de pensamiento, cuanto más espeso sea el velo de maya de su conciencia. El hombre real será un ser volente y acéfalo, y el hombre pensante que lleva a remolque un vano soñador (ibid., p. 1230).

Las consecuencias del asentamiento del irracionalismo fueron importantísimas y de varia índole, no exclusivamente filosófica. En una vertiente política y socioeconómica, y en un momento pre-nietzscheano, supuso una justificación de la inacción y del mantenimiento del statu quo, sobre la base de la existencia de un mal natural imposible de erradicar, por inherente a la condición humana. Así se entiende que, desde ciertos puntos de vista, el irracionalismo haya sido merecedor de parecidas caracterizaciones, y en el fondo descalificaciones, que las concernidas a la religión como opio del pueblo, y que el ateísmo schopenhaueriano, nada materialista, coincida en su faceta desmovilizadora con la religión así concebida: "En Schopenhauer aparece por primera vez la variante burguesa de esta corriente filosófica [el irracionalismo]. Sus principales características son éstas: desprecio del entendimiento y de la razón; glorificación lisa y llana de la intuición; teoría aristocrática del conocimiento; repulsa del progreso social; mitomanía; contenido filosófico pobre y monótono, constante y rápido descenso del nivel filosófico; nacimien- 
to sobre la base de la producción capitalista y de su lucha de clases específica, primero dentro del marco de la clase burguesa en contra del feudalismo, y luego en las condiciones de su defensiva frente al proletariado" (Romano García, 1970, p. 28). Pues el pesimismo irracionalista e individual alimenta el escepticismo sobre la intervención personal en el curso de los acontecimientos históricos -algo muy propio del privilegiado rentista que fue Schopenhauer durante toda su vida adulta-, y, ya en la teoría nietzscheana del superhombre, incita a que el genio individual termine succionando a las masas - formadas, empero, de individuos-, que delegan en él la determinación de su destino. Volveremos a ello.

Esto en lo tocante a las consecuencias de orden sociopolítico. En el orden estrictamente psíquico, la diseminación de la filosofía kantiana provocó un a modo de aparato venoso de mil y un hilillos de pensamiento, cuya propia pluralidad es causa de su debilidad, a resultas de la cual sufriría pronto la impregnación del pesimismo, tal como ha registrado netamente la literatura del ochocientos. Desde las primeras vacilaciones del edificio racionalista fue creciendo, a modo de correlato psicológico, un difuso sentimiento de insatisfacción al que me he referido como "mal de la tierra" (Pricto de Paula, 1991). Entiendo este concepto como la hipóstasis de las diferentes representaciones de la discordancia contemporánea entre el hombre y el mundo - "fastidio universal", acedia, leopardismo, taedium vitae, spleen, hastío - que han ido jalonando el sendero que va desde la desesperación romántica hasta la moderna desesperanza finisecular. (El sentimiento trágico de la vida, la náusea existencial, el absurdo, etcétera, son otras muestras de esa discordancia, sólo que propias de un tramo cronológico posterior al del fin del ochocientos.)

La filosofía, tras haber al cabo y no sin lucha aceptado explícita o tácitamente su repliegue ante el empuje del irracionalismo, tiende a verbalizarse con el lenguaje propio de la poesía, más sugeridor que denotativo, según es visible en la articulación aforística de Schopenhauer y, sobre todo, de Nietzsche, y en el encendimiento expresivo de éste último. Alguna vez, por su parte, sirve la poesía para exponer, como hace Unamuno a horcajadas entre la ironía desdeñosa y la admiración en el poema VII de Rimas de dentro (1923), la confusión derivada de la inutilidad sospechada de la filosofía (aquí kantiana) y de las relaciones entre pensamiento y realidad:

Cerré el libro que hablaba

de esencias, de existencias, de sustancias,

de accidentes y modos,

de causas y de efectos,

de materia y de forma,

de conceptos e ideas,

de nóumenos, fenómenos,

cosas en sí y en otras, opiniones,

hipótesis, teorías...

Cerré el libro y abrióse

a mis ojos el mundo.

Traspuesto había el sol ya la colina; 
en el cielo esmaltábanse los álamos

y nacían entre ellos las estrellas;

la luna enjalbegaba el firmamento,

cuyo fulgor difuso

en las aguas del río se bañaba.

Y mirando a la luna, a la colina,

las estrellas, los álamos,

el río y el fulgor del firmamento

sentí la gran mentira

de esencias, de existencias, de sustancias,

de accidentes y modos,

de causas y de efectos,

de materia y de forma,

de conceptos e ideas,

de nóumenos, fenómenos,

cosas en sí y en otras, opiniones,

hipótesis, teorías;

esto es: palabras.

Sobre el libro cerrado

que yacía en la yerba

por la luna su pasta iluminada,

mas su interior a oscuras,

descansaba una rana

que iba rondando su nocturna ronda.

¡Oh, Kant, cuánto te admiro!

(Unamuno, II, p. 82)

\section{Filtración schopenhaueriana en España}

En los aledaños de 1900, el pensamiento de Schopenhauer, no siempre separado con discernimiento del orientalismo con el que se conecta - y sin el que, por ejemplo, no puede entenderse el arte modernista-, tuvo gran importancia en la cultura española. Especialmente receptiva fue la generación literaria del fin de siglo. No falta quien sostiene o insinúa que en estas fiebres filosóficas - hay que incluir, desde luego, la provocada por Nietzsche- hubo más de epidemia intelectual que de influencias debidas a la lectura de los textos. En cualquier caso y a modo de ejemplo, es injusto el juicio de un historiador de la literatura a propósito de Baroja - y sobre todo si se quiere generalizadamente aplicar, mutatis mutandis, a los principales escritores de su generación- sobre la falta de formación filosófica del novelista vasco, malsimulada con retazos de filosofías ajenas tomados de aquí y de allá sin que nunca lleguen a cuajar en un discurso personalizado. Atribuyo la ocupación filosófica de los escritores a la persecución vitalmente sincera de unas respuestas a problemas del momento: las lecturas de libros filosóficos son la mina adonde van a buscarse respuestas a preguntas preexistentes; no adonde van a buscarse las preguntas. 
En 1889 había nacido La España Moderna, que, bajo la dirección de José Lázaro, contribuyó a introducir o consolidar en España a diversos autores europeos, Schopenhauer entre ellos, que marcaban las directrices estéticas y filosóficas de la segunda mitad del XIX. En esas páginas, por cierto, fueron publicándose en 1895 los ensayos que constituyen En torno al casticismo, de Unamuno. Fue éste quien, al estrenarse el siglo, dio a las prensas Sobre la voluntad en la naturaleza, traducción de la obra de Schopenhauer, que apareció en la editorial de B. Rodríguez Serra. En 1900 vio la luz, precisamente en la editorial "La España Moderna", la primera traducción al castellano de una obra de Nietzsche, Así hablaba Zaratustra. A partir de ese momento, pero sobre todo desde 1902 o 1903, quedaba consolidada la influencia de Nietzsche, cuyo general conocimiento por los del 98 databa precisamente de 1898, dos años antes de su muerte, a partir de la publicación de La philosophie de Nietzsche, de Henri Lichtenberger (Sobejano, 1967, pp. 47 ss.). El hecho de que Nietzsche se declarara discípulo de Schopenhauer no impidió que, eco de la temprana desviación del pensamiento de uno respecto al del otro, sus influencias intelectuales entre la corte de admiradores y discípulos hubieran de disputarse un lugar en la misma zona de sensibilidad y de cultura, de modo que llegaron a ser, en muy buena medida, excluyentes entre sí; y dígase que la de Nietzsche terminó por imponerse a la de Schopenhauer, no obstante lo cual éste siguió disfrutando de un prestigio sostenido, aunque quizás un tanto banalizado y reducido a la faceta estereotipada de su pesimismo ${ }^{4}$.

Este estereotipo, el de su incurable pesimismo, pesó mucho en la recepción de Schopenhauer en España, y ejerció una atracción que no pocas veces se confundió con la afectación artificiosa decadentista o esteticista, tal como aparece tantas veces en, por ejemplo, Villaespesa. Sólo en algunos casos se llegó más lejos, hasta la omnicomprensión del sistema de su pensamiento. Como ejemplo de la reducción de este sistema a la veta pesimista, baste citar el poema de Emilio Carrere titulado "Schopenhauer". Pero, para redondear el ejemplo, otro poema, esta vez del mejicano Amado Nervo, atribuye a Tomás de Kempis y la Imitatio Christi idénticos efectos que Carrere al filósofo de la voluntad. Al cabo, éste concordaba, en los resultados producidos, con la renunciación ascética cristiana. En ambos poemas, el sujeto accede al conocimiento de una obra — de Schopenhauer, de Kempis-que se encarga de transmitirle la verdad, tras la que su propensión hacia la belleza, los placeres de la carne y el disfrute de la vida se trueca en negación de todo ello. (Es

4 Las referencias comparativas a Nietzsche y Schopenhauer son frecuentes entre los escritores de la generación finisecular. En el Juan de Mairena machadiano hay específicamente una reflexión ("Nietzsche y Schopenhauer") en que, con la perspectiva que dan los años - ha quedado atrás la primera guerra mundial, y está a punto de iniciarse la segunda-, se valora el papel de uno y otro. Aunque A. Machado termina centrándose elogiosamente en Nietzsche, al que llama "maestro del aforismo y del epigrama" ( $y$ al que tanto debe su poesía sentenciosa y epigramática), comienza con las siguientes palabras: "Nietzsche no tuvo el talento ni la inventiva metafísica de Schopenhauer; ni la gracia, ni siquiera el buen humor, del gran pesimista. Su lectura es mucho menos divertida que la de Schopenhauer, aunque éste es todavía un filósofo sistemático y Nietzsche casi un poeta" (A. Machado, IV, p. 2109). 
curioso que, en uno y otro caso, el tono del poema derive fundamentalmente de la invocación apostrófica a quien propaló esa verdad letífica. ${ }^{5}$ )

En el trabajo de H. Jeschke La generación de 1898 en España (1934), donde se trataba de aplicar a los del 98 los criterios que había habilitado la ciencia literaria alemana para hablar de generaciones de escritores, Schopenhauer y Nietzsche aparecían como los mentores filosóficos de los noventayochistas. En efecto, uno y otro influyeron inequívocamente en Maeztu, Baroja, Unamuno, Antonio Machado. De ellos, el más nietzscheano es Maeztu, y el más schopenhaueriano Baroja, como se puede apreciar palmariamente en su colección de escritos de 1902, titulada Vidas sombrías, en Camino de perfección y, desde luego, en El árbol de la ciencia. En el caso de Baroja, cabe hablar de alternancia de novelas construidas ora bajo el influjo de uno, ora bajo el de otro: la compasión que mueve a la abulia (Schopenhauer), el dinamismo arrasador que empuja a la acción (Nietzsche), cuántas veces sin término ni sentido en los héroes de sus relatos. En opinión de Sobejano, las lecturas filosóficas de Baroja "se habían limitado hasta entonces [1899] a Fichte, Kant y Schopenhauer. Éste último le había reconciliado con la filosofía, hacia la que en principio sintió Baroja recelos de profano, según declara en Juventud, egolatría $(\mathrm{V}, 185)$. La lectura de Schopenhauer marcó huellas indelebles en su espíritu, inclinándole a meditar sobre el dolor - tema de su tesis doctoral- y a considerar la compasión como la suprema virtud" (Sobejano, 1967, p. 348). Una obra de autobiografismo encubierto como El árbol de la ciencia confirma esas influencias: "La palabrería de Letamendi produjo en Andrés un deseo de asomarse al mundo filosófico, y con este objeto compró en unas ediciones económicas los libros de Kant, de Fichte y de Schopenhauer" (Baroja, 1983, p. 41); el último, en fin, le pareció "un consejero chusco y divertido". Son palabras que se repiten, con las mínimas y necesarias modificaciones, en su obra autobiográfica Familia, infancia y juventud (V, viII), conformante de Desde la última vuelta del camino.

5 Transcribo unos versos de "Schopenhauer", de Emilio Carrere: "Viejo Schopenhaucr, doloroso asceta, / siniestro filósofo y amargo poeta: / ¿por qué me dijiste / que el amor es triste, que el bien es incjerto? / ¿Por qué no callaste que el mundo es tan triste? / ...jAunque sea cierto! / Yo amé a las mujeres. ¡Oh carne fragante, / senos en flor, dulce misterio sensual! / ¡ Yo amaba la gloria, divina y radiante, / envuelta en un áureo fulgor de ideal! / Yo amaba la vida; / pero tú dijiste que todo es dolor, / que el amor es carne sensual y podrida, / iy ya nunca tuve ni gloria ni amor! / Y ya por el mundo voy igual que un muerto. / Tu voz emponzoña todo lo que existe. / Dime, viejo horrible, aunque sea cierto: / ¿por qué no mentiste? / Agreste filósofo de las negaciones, / yo era soñador, y crédulo, y fuerte; / tú has roto el encanto de mis ilusiones / y me das la fría verdad de la muerte"; etcétera (en AA. VV., Las mil mejores poesías de la lengua castellana, Madrid, Ediciones Ibéricas, 1972, pp. 636-7). Y otros de "A Kempis", de Amado Nervo: "Ha muchos años que busco el yermo, / ha muchos años que vivo triste, / ha muchos años que estoy enfermo, / iy es por el libro que tú escribiste! // ¡Oh Kempis, antes de leerte, amaba / la luz, las vegas, el mar Oceano; / mas tú dijiste que todo acaba, / que todo muere, que todo es vano! // Antes, llevado de mis antojos, / besé los labios que al beso invitan, / las rubias trenzas, los grandes ojos, / ¡sin acordarme que se marchitan! // Mas como afirman doctores graves, / que tú, maestro, citas y nombras, / que el hombre pasa como las naves, / como las nubes, como las sombras..., // huyo de todo terreno lazo"; etcétera (Obras completas, II, Madrid, Aguilar, 1972, $4^{2}$ ed., $1^{a}$ reimpr., p. 1322). El tono apostrófico es más increpante, como se ve, en el poema de Carrere que en el de Nervo; pero no deja de producir curiosidad la similitud esencial entre uno y otro. 
La razón de que el impacto de Schopenhauer sobre la cultura española fuera, al menos parcialmente, anonadador, se debe a la afinidad entre las preocupaciones de ésta y las propuestas de aquél, novedosas por su perspectiva no occidental ni cristiana. Pues la filosofía de Schopenhauer no supone una mera transformación evolutiva del pensamiento precedente, sino un cercenamiento - no total, según se ha sugerido antes y se desarrollará después - respecto a éste. Mientras que el grueso del pensamiento occidental descansa sobre las bases humanistas del cristianismo, Schopenhauer se opone a toda ilusión telúrica o ultratelúrica (y ello independientemente de que, como él mismo afirmara en diversas ocasiones, el meollo del perfeccionamiento cristiano tuviera concomitancias con sus propias tesis). Y mientras que la filosofía occidental parte de un concepto de realidad cuyo soporte es el logos, de modo que la realidad aparece vinculada sin solución de continuidad al razonamiento humano, en Schopenhauer esta categoría es destituida por una ciega, irracional y perennemente insatisfecha voluntad de vivir. Así que la remoción filosófica que lleva a cabo Schopenhauer lo es por partida doble: en lo que respecta al hilo de continuidad cristiano, por un lado; en lo relativo al racionalismo, por otro. Al cristianismo opone la negación de la esperanza; al racionalismo, el voluntarismo. Añádase a ello la atracción general de Schopentiauer por la cultura asiática, pareja a la que sentiría Occidente en el tránsito del siglo XIX al XX, y de la que en el ámbito hispánico dio cuenta el arte finisecular. Constreñida por un racionalismo incapaz de aliviar el dolor de la existencia, la cultura europea busca en veneros orientales el agua que apague su sed. No otro sentido tiene -aunque no sea éste el lugar de explicarlo: hay abundante bibliografía sobre el lema- el exotismo orientalista del Modernismo, por más que sus propios cultivadores no siempre acertaran a penetrar en la pulpa, quedándose perdidos algunos de ellos en un bazar donde las chinoiseries, japoneries y otras baratijas de escaparate les impidieron ver la trastienda espiritual.

Había, por cierto, una dificultad de principio para que cuajara en la literatura española el pensamiento del filósofo: el carácter proteico de sus exposiciones, con cruces temáticos y sin una acotación estricta de sus contenidos, apenas aislables, que pasan de una obra a otra en un relativo enmarañamiento: "Schopenhauer es un pensador que no tematiza [...], que no aísla, por lo general, con claridad unos temas de otros para realizar su tratamiento separado y sistemático. Esto conduce, por una parte, a que se encuentren en la obra de Schopenhauer muchas repeticiones, es muy reiterativo como él mismo confesará: constantemente retoma una y otra vez idénticos temas y vuelve sobre las mismas afirmaciones, lo que no quiere decir que no vaya añadiendo algo nuevo cada vez, al realizarse una misma afirmación en diferente contexto" (Rábade, 1989, p. 8). Ello atenta, en principio, contra la cristalización conceptual del sistema, en un orden pedagógico. Pero actúan de ventajoso contrapeso otras circunstancias que terminan por allanar todas las dificultades para esta naturalización del schopenhauerismo en España. Una es la fluidez y el apasionamiento expositivos, más habituales en un polemista mundano que en un filósofo 
(Schopenhauer es un filósofo "fácil"). Otra es la esencial fijeza del pensamiento schopenhaueriano a lo largo de la vida del autor. Sus reiteraciones, digresiones, anécdotas u observaciones fulgurantes "a lo Rochefoucault" flexibilizan el discurso o lo disponen en tal o cual dirección, pero no alteran las estructuras básicas de su filosofía, que aparece constituida en fase muy temprana. Frente a filósofos cuyos títulos de madurez se alejan de los planteamientos iniciales, los escritos del Schopenhauer maduro (Sobre la voluntad en la naturaleza, Los dos problemas fundamentales de la ética, Parerga y paralipomena, o el corpus fragmentario y aforístico que quedó inédito a su muerte) son, en buena medida, o la consolidación de un aspecto de su "obra principal" — por utilizar la jerarquización machaconamente establecida por él mismo-, El mundo como voluntad y representación $(1819)^{6}$, o la derivación de la tesis de esa obra en una línea concreta del ámbito moral, o la exposición de recientes descubrimientos en el campo de las ciencias naturales que, scgún él, confirmaban el edificio de su metafísica tal como aparece en El mundo como voluntad y representación. A los treinta años de su autor quedaba, pues, configurado en sus fundamentos el pensamiento del gran pesimista, que dedicó el resto de su vida a pulir o dar luz a tal o cual faceta del mismo. Esta compacidad estática del pensamiento contribuyó, en sentido contrario al desdén con que se le consideró en Alemania hasta bien entrada su madurez, al aprecio de que gozó en la España de fines del siglo XIX.

\section{Muerte de la ilusión eudemonista}

El elemento vertebral de la filosofía de Schopenhauer es la consideración de la realidad percibida como una representación (Vorstellung) engañosa y multiplicada de la "cosa en sî" kantiana (Ding an sich), a la que Kant no pudo dar nombre. Ésta no es otra que la voluntad (Wille), auténtico fundamento del mundo y, en cuanto que se sitúa fuera del campo fenoménico de la representación, incognoscible. La voluntad es, stricto sensu, voluntad de vivir: "Cuanto quiere la voluntad siempre es vida, dado que ella misma no supone sino la presentación de ese querer de cara a la representación; en este sentido, no deja de ser una y la misma cosa, un mero pleonasmo, el hablar de 'voluntad de vivir', en lugar de decir sin más 'voluntad"' (Schopenhauer, 1993, p. 6). Se trata de un afán que pugna por afirmarse frente a todo lo demás, y cuya insaciabilidad contiene inherentemente el dolor de la existencia, tanto si se consigue una momentánea satisfacción de los anhelos como si no. Si los deseos pueden considerarse apelaciones al futuro, en la filosofía de Schopenhauer los deseos cumplidos nos liberan, precisamente, de esos mismos - pero no de otros-deseos prospectivos, con lo que no nos encontramos mejor que antes:

6 Los títulos originales de las obras citadas son, en ese mismo orden: Ueber den Willen in der Natur, Die beiden Grundprobleme der Ethik, Parerga und Paralipomena, Die Welt als Wille und Vorstellung. También se cita en el cuerpo del trabajo Der handschriftliche Nachlass (El legado manuscrito). 
Toda vida humana fluye entre el querer y el conseguir. El deseo supone dolor, conforme a su naturaleza; el logro alumbra de inmediato a la saciedad. El objetivo sólo era aparente; la posesión aniquila el estímulo. El deseo adopta una nueva configuración y la necesidad reaparece; y cuando no ocurre así, hacen acto de presencia la tristeza, el vacío y el aburrimiento, contra los que la lucha resulta tan penosa como contra la necesidad (Schopenhauer, 1993, p. 57).

Las palabras del maestro de Antonio Azorín, el Yuste de La voluntad, son definitivas y concordantes con esta consideración del filósofo: "El arte sintetiza el desencanto del esfuerzo baldío... o el más terrible desencanto del esfuerzo realizado..., del deseo satisfecho" (Azorín, 1982, p. 118). Camino de perfección, de Baroja, es una novela que ha de leerse en cotejo con la anterior, pues ambas nacieron de una misma pulsión creativa. Uno de los muchos personajes desparramados en ella, el arriero Nicolás Polentinos, expone en el capítulo XVII algunas consideraciones que, en versión rural y muy elemental, se atienen a estas mismas ideas: insaciable.

-Es que usted, señor Nicolás, y dispénseme usted que se lo diga, es usted

-Y todos los hombres lo son, créalo usted, y como no se pueden saciar todos los deseos, porque el hombre es como un gavilán, pues vale más no saciar ninguno. ¿Usted no cree que se puede vivir en una casa de locos encerrado y ser más feliz con las ilusiones que tenga uno, que no siendo rico y viviendo en un palacio?

-Sí. Es posible.

-Claro. Si la vida no es más que una ilusión. Cada uno ve el mundo a su manera. Uno lo ve de color de rosa, y otro negro. i Vaya usted a saber cómo será! Es posible que no sea también más que una mentira, una figuración nuestra, de todos.

Y el señor Nicolás hizo una mueca de desdén con sus labios gruesos y belfos y siguió hablando de la inutilidad del trabajo, de la inutilidad de la vida, de lo grande y niveladora que es la muerte (Baroja, 1974, pp. 119-20).

En pocas palabras están resumidos algunos rasgos del pensamiento de Schopenhauer: insaciabilidad de nuestros deseos; renuncia como ideal; realidad ilusoria, pues el mundo fenoménico sólo tiene existencia para un sujeto, es simple y engañosa representación.

La suplantación de la razón por parte de la voluntad rompe una inercia filosófica que venía funcionando desde muchos siglos atrás en la conciencia occidental. Así lo ha expresado Antonio Machado: "Quizás no se ha señalado la enorme trascendencia que, para el alma occidental, supone el hecho de la filosofía de Schopenhauer. Su pesimismo y su valoración negativa de la vida - que no es nada esencial en su filosofía- ha desviado la atención y encaminado el interés de muchos lejos del tema importante" (A. Machado, III, p. 1354). Algo se ha sugerido atrás, al aludir al estereotipo del pesimismo existencial que hemos ejemplificado en Carrere, desvinculado de las razones metafísicas que pretendidamente lo explican. 
Espontánea y ciega, poderosa y avasalladora?, la voluntad no es objeto de decisión: ella pone en marcha el mecanismo de las determinaciones. No debe, pues, confundirse con el albedrío, en el que participa el intelecto, el cual examina racionalmente los instintos en que estas fuerzas se exteriorizan. Esta distinción entre voluntad y (libre) albedrio es central en la filosofía de Schopenhauer; convendrá, pues, escucharlo a él, que discierne entre ambos, en Sobre la voluntad en la naturaleza: "Albedrío se llama a la voluntad cuando la alumbra el intelecto, siendo, por lo tanto, las causas que le mueven a motivos, es decir, representaciones, lo cual, expresado objetivamente, quiere decir que la influencia del exterior, que es lo que ocasiona el acto, se mediatiza por un cerebro" (Schopenhauer, 1979, p. 65).

En otras corrientes filosóficas muy influyentes en la cultura española del ochocientos, la construcción metafísica generó una ética - convertida al fin en un "estilo de vida" - que terminaría imponiéndose sobre cualquier consideración teórica, y hasta prescindiendo de ella; es así el proceso que se da, por ejemplo, en el avance de la novísima filosofía krausista, importada por Sanz del Río, a sus irradiaciones krausopositivistas de talante regeneracionista o pedagógico. Más aún: en la cultura literaria no suele calar la fundamentación metafísica de un corpus de pensamiento sino sus efectos prácticos, susceptibles de traducirse en tipos narrativos, en rasgos conductuales, en estados de ánimo. En el caso de Schopenhauer y la cultura española, hubiera sido lógica esta suplantación a que me refiero, lo que se correspondería, por otra parte, con la minusvaloración que se da en el budismo, tan influyente en aquél, de la especulación filosófica: la verdad no es tan importante como la medicina ética que se utiliza para aplacar el mal de la existencia. Ahora bien, con Schopenhauer ocurre algo absolutamente peculiar en cuanto a la vinculación entre filosofía teórica y filosofía moral, pues si, según expone en El mundo como voluntad y representación (libro IV, parágrafo 66), una moral meramente prescriptiva, que no esté fundada en la razón, carece de valor, ya que no brinda motivos, inversamente una moral que dé motivos carecería también de valor, ya que no podría sino sustentarse en el egoísmo, condición natural del hombre que se mueve por la voluntad.

La proposición de Schopenhauer es radical: los modos positivos de formulación moral son eudemonismos tan cómodos como falsos, pues atrapan al ser en la red del mejor de los mundos posibles, aquel en que hacemos coincidir lo que egoístamente nos interesa con lo verdadero y lo bueno. El ejercicio de desenmascaramiento schopenhaueriano consiste en sacar a la luz tales maquinaciones, y mostrar que todas estas morales de la felicidad no son otra cosa que la hipóstasis ideológica del egoísmo, que viene de la mano, éste sí naturalmente, de la voluntad.

En El cirbol de la ciencia, se refiere Andrés Hurtado a la destrucción que lleva a cabo Schopenhauer de "esa gruesa rama del árbol de la vida que se llama libertad, responsabilidad, derecho" (Baroja, 1983, p. 133), que aún Kant había amorosamente dejado en pie; lo que da entrada a una plástica consideración sobre la voluntad: "y la vida aparece como una cosa oscura y cicga, potente y jugosa, sin justicia, sin bondad, sin fin; una corriente llevada por una fuerza X, que él llama voluntad" (p. 134). 
En tal sentido, la novedad schopenhaueriana, según la vieron los escritores españoles que se formaron en ella, es absoluta. Schopenhauer es un vir novus, de la saga de héroes que no sólo asisten impávidos a la muerte del Cristo, sino que contribuyen a ella, a sabiendas de que esa muerte supone quemar todas las naves de la ilusión eudemonista, y situarse en un punto sin retorno, en el que todo optimismo filosófico queda abolido: "Con Schopenhauer se inicia la serie de hombres trágicos que, como Wagner y Nietzsche, pretenderán vivir la muerte del dios cristiano como un desesperanzado dolor que no se negará a sí mismo, sino que, por el contrario, pretenderá aceptarse sin paliativos ni consuelos y hasta con orgullo; para todos los hombres de esta especie siguen siendo válidas las palabras que Federico Nietzsche dedicara a Schopenhauer en su Consideración intempestiva, al presentárnosle como 'cl guerrero que desde las simas del escepticismo y de la renunciación crítica nos conduce a la cima de la contemplación trágica, en tanto que la infinita bóveda estrellada se despliega sobre nosotros"' (González Noriega, 1979, p. 9). Las palabras de Nietzsche, que en su arranque filosófico consideraba a Schopenhauer un excelente educador, exponen un juicio concordante con el que, en el siglo I a.C., formula Lucrecio acerca de ese otro héroe que resultó ser Epicuro, cuya doctrina explana en De rerum natura, por el hecho de que el de Samos se atrevió a erigirse contra la superchería religiosa - el pensamiento epicureísta identifica religión y superchería religiosa: ambas son uno y lo mismo- - que, a la altura del siglo IV, tenía sojuzgados y amedrentados a los hombres por el terror a la muerte y el terror a los dioses, bastiones ambos de la religión ${ }^{8}$. Pero las enseñanzas de Schopenhauer no están exentas de un valeroso aventurerismo que las hace sumamente atractivas. Así lo entendía el buen obispo oriolano de la novela de J. Martínez Ruiz Antonio Azorín (1903), que convida a comer a Sarrió y a Azorín, y para quien Nietzsche, Schopenhauer y Stirner "son los bellos libros de caballería de hogaño" (Azorín, 1982,p. 211) que arrastran a muchos jóvenes por las veredas de sus pensamientos descarriados.

8 "Humana ante oculos foede cum uita iaceret / in terris, oppressa graui sub religione / quae caput a caeli regionibus ostendebat / horribili super aspectu mortalibus instans, / primum Graius homo mortalis tollere contra / est oculos ausus primusque obsistere contra; / quem neque fama deum nec fulmina nec minitanti / murmure compressit caelum, sed eo magis acrem/inritat animi uirtutem, effringere ut arta / naturae primus portarum claustra cupiret. / Ergo uiuida uis animi peruicit, et extra / processit longe flammantia moenia mundi / atque omne immensum peragrauit mente animoque, / unde refert nobis uictor quid possit oriri, / quid nequeat, finita potestas denique cuique / quanam sit ratione atque alte terminus haerens. / Quare religio pedibus subiecta uicissim / obteritur, nos exaequat uictoria caelo" (Lib. I, 62-79). En mi traducción: "Cuando el género humano se arrastraba / en la tierra, oprimido por el peso / de la superchería religiosa, / que amedrentaba con horrible mueca / desde el cielo a los hombres, hubo un griego / que alzó por vez primera su mirada / mortal a las alturas, declarando / guerra a la religión. Y no lograron / hacerlo desistir ni las leyendas / de los dioses, ni el rayo, ni el bramido / espantoso del cielo. Antes con esto / creció el valor de su ánimo arrojado / y su deseo de romper las sólidas / cerrajas de las puertas que protegen / los secretos de la Naturaleza. / Al fin venció su gran poder de espíritu, / y con la fuerza de su pensamiento / fue mucho más allá de las murallas / flamígeras del mundo, atravesando / el Todo inmenso en peregrinación. / Y, como vencedor, de allí regresa / con la sabiduría: si esto pucde / o no puede nacer, qué leyes rigen / la potestad de cada cosa, y cuáles / son sus exactos límites. Por ello, / la religión, ahora sometida, / a nuestros pies se humilla; y a nosotros / la victoria nos alza hasta los cielos" (De la Naturaleza. Selección, Alicante, Aguaclara, 1992, pp. 17-8). 


\section{La compasión y sus obstáculos}

Así las cosas, la única base moral consistiría "en la percepción intuitiva de la unidad radical que subyace a todos los seres. Lo expresa mejor que nadie el sanyasin hindú que repite ante cada una de las realidades del mundo su tat twam asi; tú eres eso, somos — cada cual- fundamentalmente idénticos a los demás y a todo lo que nos rodea. El velo de Maya de la individualidad, causa de los dolores y enfrentamientos entre los seres, se desvanece en esta intuición y surge el auténtico fundamento de toda conducta eficazmente moral, la compasión" (Savater, 1992, p. 508). La compasión es, en fin, un cortocircuito que se produce en el ciclo de la voluntad. Ésta se expresa individualmente en el egoísmo: imposición del yo, que tiende naturalmente a arrasar motivaciones ajenas, sobre lo otro. Frente a él se sitúa el sentimiento de la compasión, punto de encuentro de diversas culturas, épocas y ámbitos geográficos: budismo, pietas virgiliana, cristianismo. Pero si el budismo se basa en la universalidad del dolor en que se resuelve la existencia, el cristianismo supone la actualización de la pietas virgiliana, intensificando la idea de una fraternidad fruto de la común procedencia - de seres vivos y universo- de un mismo Padre creador. La compasión es análoga, también etimológicamente, a la simpatía ('sentimiento con', 'sufrimiento con'), aunque en la formulación cristiana lo que prevalece ya no es el con-sentimiento sino la conmiseración: tener piedad de.

En la filosofía schopenhaueriana, la compasión - por influencia del pensamiento búdico y brahmánico, como se verá- es antes cósmica que humana. Frente a la antropocracia occidental y cristiana que hace del hombre el rey de la naturale$z a$, a cuyos otros componentes esquilma, maltrata y muchas veces destruye, Schopenhauer pone el acento en la unidad de todo y en la pertenencia de cada quien a la realidad global. Para Schopenhauer, la compasión no es sólo un deber como lo es fundamentalmente para los estoicos-, ni se identifica con la tristeza proveniente ex alterius damno — como para Spinoza—, ni deriva de cualquier tipo de complicidad entre los débiles -que valió las críticas de Nietzsche contra una piedad que es finalmente la justificación de las mezquindades propias ${ }^{4}$ - , sino que constituye el paso preliminar de la negación del vivir, hasta la que conduce, como modo de reconocimiento de que el dolor producido en el paso de la voluntad a la consciencia es un dolor del que todo ser es partícipe, pues procede de la muerte que

Contra el entendimiento de la compasión como virtud de los débiles, tal como lo difundió el pensamiento nietzscheano, se alza Unamuno en uno de los sonetos incluidos en Poesías (1907). Mc refiero concretamente al titulado "Piedad", que no es una perla lírica, pero ofrece una clave de interés para la interpretación de Unamuno y su sentimiento de la compasión: "Busca de tu alma la raíz divina, / lo que a tu hermano te une y asemeja / y del puro querer que te aconseja / aprende fiel la santa disciplina. // Oye a tu humanidad cual te adoctrina: / Todos soy yo, en mi alma se refleja / todo placer y toda humana queja’, / y del falso vigor siempre abomina. // Los débiles forjaron la patraña / de que no obras de amor, sino de ira / todo progreso cual ci iniento entraña, // mas en vano la mente con mentira / la luz del corazón cuida que empaña, / que al fuerte siempre la piedad le inspira" (Unamuno, I, p. 226). 
hay en la aspiración a la vida: en este sentido de la compasión, "yo soy el otro". Dada la esencial unidad psicovital de los seres, a la maldad moral se añade la necedad cuando, mediante el ejercicio de la crueldad, el hombre provoca dolor a los prójimos, sin considerar que el dolor infligido revierte en quien lo genera. En $E l$ legado manuscrito, III, Schopenhauer desvela en clave teísta un sentimiento en el que la compasión por el dolor universal tiene más fuerza que el contenido deprecatorio contra un hipotético dios generador del mal cósmico: "Si este mundo lo ha hecho un dios, no quisiera yo ser él: los ayes del mundo me romperían el corazón" (Schopenhauer, 1995, p. 53).

Así pues, esta filosofía atormentada induce a barrer el egoísmo connatural al hombre. Mas el aristocratismo de Schopenhauer, y su odio - flaubertiano avant la lettre- a la bêtise o estupidez ajena, que lo llevó en innúmeras ocasiones a ponderar la soledad (el hombre eximio maduro sabe ya que quienes lo rodean no pueden seguirlo), obstaculizan extraordinariamente el propósito antiegoísta. Piedad, compasión, simpatía: nada de ello exime, empero, de la dificultad misantrópica de esa obligación autoimpuesta de sentirse uno con los demás hombres: "Debemos amar a los scres humanos. ¡Qué tarea tan difícil!" (Schopenhauer, 1995, p. 75). Pues tan natural como el egoísmo es el desdén de quien destaca por los mediocres que se conjuran para asfixiarlo. Este aristocratismo es, no menos que schopenhaueriano, nietzscheano, aunque también puede obedecer a la propia tradición de altivez ascética y senequista y a la aplicación del impulso heroico a la redención del presente, como en Los trabajos del infatigable creador Pío Cid, de Ganivet. Por lo demás, la tarea de la compasión no puede ignorar que, por ella misma, provoca también malestar en cuanto que supone concordancia y aproximación que entorpecen el desarrollo insobornable del yo. En Parerga y paralipomena, II, relata Schopenhauer la fábula de los puerco espines, con su corolario bien explícito:

En un frío día de invierno un grupo de puerco espines se acercaron mucho los unos a los otros, apretujándose, con el fin de protegerse, mediante el mutuo calor, de quedar helados. Pero pronto sintieron las recíprocas púas, que los hicieron distanciarse otra vez a los unos de los otros. Mas cuando la urgencia de calentarse volvió a acercarlos, se repitió otra vez la misma calamidad, de modo que eran lanzados de acá para allá entre uno y otro mal, hasta que por fin encontraron una distancia moderada entre ellos, en la que podían mantenerse óptimamente. Así es como la necesidad de compañía, brotada de la vaciedad y monotonía de su propio interior, empuja a las personas a juntarse; pero sus muchas propiedades repulsivas y sus muchos defectos intolerables vuelven a apartarlas violentamente. La cortesía y las costumbres delicadas son la distancia media que acaban encontrando y con la cual puede subsistir una coexistencia entre ellas. En Inglaterra, a quien no mantiene esa distancia le gritan: Keep your distance! Es cierto que mediante ella se satisface sólo de manera incompleta la necesidad de mutuo calentamiento, pero, en compensación, no se siente el pinchazo de las púas. Ahora bien, quien tiene mucho calor interior propio prefiere permanecer alejado de la sociedad, para no dar molestias ni recibirlas (Schopenhauer, 1995, pp. 13-4). 
Cualquier lector de Luis Cernuda conoce las palabras, alusivas a la parábola que acabo de transcribir, que figuran como pórtico a Donde habite el olvido, el libro escrito entre 1932 y 1933 en que da cuenta dolorida de un fracaso amoroso. El propio Cernuda afirmó que la relectura de ese libro le producía, por el confesionalismo tan explícito, "rubor y humillación". El encuentro erótico, y el desencuentro siguiente, dan pábulo al libro, encabezado por la actualización de la fábula de Schopenhauer — cuyo nombre no cita — llevada al molino de su apasionada vivencia:

Como los erizos, ya sabéis, los hombres un día sintieron su frío. Y quisieron compartirlo. Entonces inventaron el amor. El resultado fue, ya sabéis, como en los erizos (Cernuda, 1975, p. 88).

La voluntad es tan poderosa que tiende a imponerse de una forma u otra, arrasando los débiles obstáculos que tratan de frenar su empuje, y anegando de dolor la existencia entera. Y, sin embargo, sólo puede accederse a un estado elevado de moral quebrando ese avance, negando, en suma, la voluntad para así atenuar y finalmente eliminar el dolor en que consiste nuestra vida individual. El cercenamiento y la renunciación personales son la vía de elección, extraordinariamente ardua por cuanto la voluntad está íntimamente incrustada en nuestras motivaciones: imponerse a ella arrancándola de nuestro ser hasta "matar" la motivación egoísta y apagar la sed supone atentar contra ese ser mismo (no, por cierto, mediante el suicidio: éste es una afirmación irrestricta de la voluntad). De modo que, paradójica - y no sólo tautológica- pescadilla que se muerde la cola, la abolición del egoísmo se explica por una motivación, al cabo, "egoísta": la de cortar a cercén la línea que conduce de la voluntad al egoísmo, y de éste al dolor. Claro que, como en una lobotomía cerebral, la supresión del dolor es un ejercicio que no se engaña con promesa alguna de felicidad, y se opone tanto al dolor como a la felicidad, y en suma a la vida. Una vez se ha percatado del mecanismo del dolor derivado de la voluntad de vivir, la consciencia es capaz de provocar la negación de ese afán: al tiempo que descubre el sufrimiento que comporta la existencia - y que no percibe quien vive en las brumas de la ignorancia o de la insensibilidad-, halla igualmente el procedimiento para acabar con él, mediante la contemplación de las ideas y, al fin, la desvinculación del loco anhelo de vivir. De modo que la sabiduría es condena y puede ser redención. Como en el viejo Eclesiastés, "creciendo el saber, crece el dolor" $(1,18)$, pero, en tanto que el hombre vulgar es un ser inconsciente ante el dolor en que la vida consiste, e intenta satisfacer esos apetitos que son de suyo insaciables, la persistencia en la contemplación puede conducir a la liberación. La desigualdad entre las fuerzas de la voluntad y las de la inteligencia hará preciso el concurso, junto a la última, de otros elementos coadyuvantes para conseguir la determinación de vencer a la voluntad. Entre ellos, los desengaños vitales o el propio impulso religioso, $\mathrm{y}$, sin duda, también el arte, que contribuye a hacer palmarias las ideas eternas. Aquí es donde cobra, dentro del sistema schopenhaueriano, 
toda su importancia la música y, en menor medida, la poesía. Por lo demás, no todos los tiempos de la vida del hombre son igualmente dados a la preeminencia de la voluntad irracional. La infancia se caracteriza por una mirada poética y objetiva, dado que está más concernida por el conocimiento que por la voluntad, aún sin la pujanza que más tarde tendrá, razón por la cual la dicha infantil se rememora, en la edad adulta, con evidente nostalgia.

\section{El sometimiento de la voluntad}

Matan la motivación egoísta y sojuzgan la voluntad quienes truncan las expectativas de la procreación y atentan, allí en su centro, contra la acaso más señalada impulsión de la voluntad, que pugna fervientemente por perpetuarse. El sexo es, para Schopenhauer, concreción evidente y ardorosa de la voluntad sin mezcla ${ }^{10}$, tal como afirma en El mundo como voluntad y representación, y la vida del hombre, esencial y duraderamente dolorosa, es la paráfrasis del coito: afirmación la más neta de la voluntad de vivir. La castidad supone, en consecuencia, dar un tajo al cordón umbilical que nos ata a los anhelos más fuertes ${ }^{11}$.

En cuanto sometimiento de la loca voluntad, la cultura occidental no puede ofrecer muchos ejemplos mejores que el de los ascetas que se mortifican, y los monjes que renuncian a las pompas del egoísmo mediante los votos de pobreza, obediencia $y$, por lo que se acaba de exponer, sobre todo castidad. Así se señala en las siguientes palabras de Schopenhauer, pertenecientes a El legado manuscrito, III, en que elogia a quienes se encierran en vida y atenúan la intemperancia de la absoluta renunciación compartiendo soledad con otros solitarios (nótese el acomodamiento a un vago epicureísmo y la incitación a la medianía, que indican una actitud, aunque dura, menos inhumana que la que propone en los momentos fundamentales de su obra):

10 Unamuno, en el comentario que redacta a propósito del soneto XCVIII ("La gana, la real gana, es cosa vana"), incluido en De Fuerteventura a París (1925), alude a la diferencia entre gana y voluntad, y en relación con ello escribe: "Sabido es que Schopenhauer, el pesimista, nos admiraba a los españoles, y nos admiraba en virtud de su pesimismo, porque hacemos radicar la pura voluntad, la voluntad ciega, la voluntad sin inteligencia, en los órganos genitales del macho, en la 'masculinidad completamente caracterizada', que dijo el Primo [de Rivera] en su Manifiesto. La gana va a dar a la nada, otro concepto muy castizo. ¿Por qué Amiel, en su Diario íntimo, pone la palabra nada en español? Y la nada produce el nadismo, que es el nihilismo español castizo, el quietismo de Miguel de Molinos, el aragonés" (Unamuno, II, pp. 345-6).

"Mientras que la voluntad se expresa en estado puro en el coito, la concepción implica la entrada de la voluntad en la luz del conocimiento reflexivo, reapareciendo así la posibilidad de redención de la irracionalidad voluntariosa; según afirma en El legado nanuscrito, III, "Esto nos hace ver que en cierto sentido el embarazo trae consigo, o al menos promete, una cancelación de la deuda contraída por el coito. El coito porta toda la vergüenza y toda la ignominia; y el embarazo, tan hermanado con él, permanece puro e inocente e incluso se vuelve honorable en cierta medida" (Schopenhauer, 1995, pp. 32-3). 
Un monasterio es una concurrencia de personas que han hecho voto de pobreza, castidad y obediencia (es decir, de renuncia a su propia voluntad) y que, conviviendo, intentan aliviar en parte la existencia, pero más aún aquel estado de pesada renuncia, ya que el ver a otras personas que tienen el mismo sentir y que han hecho iguales renuncias refuerza su decisión y las consuela. $Y$, además, en muchas y pesadas privaciones la socialidad de la convivencia, con ciertas restricciones, constituye un desahogo inocente y adecuado a la naturaleza humana. Ése es el concepto normal de monasterio. ¿Y quién puede llamar a semejante grupo de personas una asociación de necios y locos, como es preciso hacerlo según todas las filosofías menos la mía? (Schopenhauer, 1995, pp. 109$10)$.

Una de las novelas centrales de 1902, La voluntad azoriniana, presenta el proceso que conduce a este estado de renunciación en la persona de Justina, la sobrina del clérigo Puche, que durante un tiempo aparece como la enamorada del irresoluto Antonio Azorín, hasta que ingresa en el convento donde morirá al poco. Pero antes de su muerte física (la segunda parte se inicia con una alusión a la muerte de la joven, a raíz de la cual el protagonista deja el pueblo y marcha a Madrid) se ha producido una otra muerte, la de la voluntad, ejemplarmente expresada en el momento en que concluye el ritual de ingreso como novicia en el convento:

Acabado el himno, las monjas susurran: Kyrie eleison, Christe eleison, Kyrie eleison, Pater noster... Y mientras Justina yace con Ias finas manos cruzadas sobre el pecho, pálida, con los ojos cerrados, el sacerdote va rociándola con agua bendita.

La ceremonia acaba. Justina se levanta y va entre las monjas a besar el altar; después le besa la mano a la abadesa; luego abraza una por una a las religiosas, diciéndoles: "Ruegue a Dios por mî". La comunidad entona el salmo Deus misereatur nostri y se dirige hacia la puerta.

$\mathrm{Y}$ las monjas van desapareciendo, la puerta torna a cerrarse, el coro queda silencioso... Justina es ya novicia: su Voluntad ha muerto (Azorín, 1982, p. 113) ${ }^{12}$.

La profesión en un convento aparece en diversos relatos del primer tercio del siglo asociada a esta muerte de la voluntad (recuérdese, por ejemplo, el final de Los pies y los zapatos de Enriqueta, de Gabriel Miró, escritor muy influido por el filósofo de Dantzig). Volviendo a La voluntad, es en la tercera parte de la novela donde

12 En realidad, La voluntad es, toda ella, una novela que debe leerse al trasluz de la filosofía schopenhaueriana, si bien no es una ejemplificación de la misma, sino el tablero donde ésta se expone junto a otras corrientes, a veces en oposición o en confusión con ellas (Krause, 1948). En la técnica descriptiva y retratística de J. Martínez Ruiz cobra singular relieve la caracterización que hace del despacho de Yuste (I, 3, primer párrafo). Yuste es el magister que, en esta novela formativa, cumple la tarea de moldear espiritualmente al personaje protagonista, Azorin. Antes de presentar al propio Yuste, quien se halla paseando por la estancia y discurriendo en voz alta ante el silente Azorín, el autor ha querido dejar clara la nuclearidad de la filosofía de Schopenhauer: "El despacho es una anchurosa pieza de blancas paredes y bermejas vigas en el techo. Llenan los estantes de oloroso alerce libros, muchos libros, infinitos libros - libros en amarillo pergamino, libros pardos de jaspeada piel y encerados cantos rojos, enormes infolios de sonadoras hojas, diminutas ediciones de elzevirianos tipos-. En un ángulo, casi perdidos en la sombra, tres gruesos volúmenes que resaltan en azulada mancha llevan en el lomo: Schopenhauer" (p. 76). 
el Azorín personaje - cuya identidad ingresa a veces en la del propio autor, que llegaría a robarle el alias - se ausculta, sintiéndose vacilar entre el hombre-voluntad (cierto es que amortecido, apagado tras largos años de educación religiosa y constrictora) y el hombre-reflexión (macerado con las lecturas, soledades y reflexiones): "El que domina en mí, por desgracia, es el hombre-reflexión; yo casi soy un autómata, un muñeco sin iniciativas; el medio me aplasta, las circunstancias me dirigen al azar a un lado y a otro. Muchas veces yo me complazco en observar este dominio del ambiente sobre mí, y así veo que soy místico, anarquista, irónico, dogmático, admirador de Schopenhauer, partidario de Nictzsche" (p. 152). Como es propio de tantos héroes noventayochistas - y combinando los dos elementos que constituían para Schopenhauer la existencia en general-, la vida de Antonio Azorín oscila entre el horror y el tedio. Si la escapatoria es la muerte de la voluntad, parece que Antonio Azorín no está realizando un ejercicio positivo de estrangulamiento de la misma, sino que se encuentra en ese abandono en que queda el ser cuando ha dejado de combatir para holgarse en su propia postración. Lo uno es la ataraxia; lo otro es sólo la abulia (Prieto de Paula, 1993). Así, en el capítulo cuarto de la tercera parte, que describe la estancia del personaje en el convento jumillano de Santa Ana, luego de que éste haga diversas reflexiones versátiles sobre la voluntad ("La Voluntad en mí está disgregada; soy un imaginativo"; "Y después de todo, ¿para qué la Voluntad? ¿Para qué este afán incesante que nos hace febril la vida?", p. 152), establece la diferencia entre los monjes y él, unos y otro carentes de voluntad: aquéllos porque han llegado a una imperturbabilidad - analogía cristiana de la ataraxia epicúrea - resultado de su desprecio de la voluntad, derrotada al fin; él porque es un abúlico: "Yo simpatizo con estos frailes porque en cada uno de ellos me contemplo retratado; en ellos veo hombres que desprecian la voluntad, esa voluntad que yo no puedo despreciar... porque no la tengo" (p. 153). Al estado de novoluntad como abulia, frente al de no-voluntad como ataraxia, se refiere casi inmediatamente Antonio Azorín:

Dejemos que cada cual siga en paz su camino. Yo voy al mío. Y el mío es el de ese pueblo donde he nacido, donde me he educado, donde he conocido a un hombre, grande en sus debilidades; donde he querido a una mujer, buena en su fanatismo; donde acabaré de vivir de cualquier modo, como un vecino de tantos, yendo al casino, viniendo del casino, poniéndome los domingos un traje nuevo, dejando que el juez me venza en una discusión sobre el derecho de acrecer, soportando la vergüenza de no saber disparar una escopeta, ni de jugar al dominó, ni de decir cosas tontas a las muchachas tontas... (p. 153)

Ya sabemos de qué modo es el final - $i$ definitivo realmente? - que aparece prenunciado aquí por quien habrá de vivirlo: recluido en el pueblo levítico, soportando a la extensa familia de su mujer, descuidado de sí, ahormado en la humillación. Pero antes ha vislumbrado el paraíso ataráxico al que accedería la humanidad si, un día, renunciara a su afán de propagarse en el dolor de la existencia, y hasta llega a columbrar la plenitud que se seguiría de la determinación de arrumbar defi- 
nitivamente la voluntad de la procreación: "Entonces, si la Humanidad se decidiera a renunciar a este estúpido deseo de continuación, viviría siquiera un día plenamente, enormemente; gozaría siquiera un instante con toda la intensidad que nuestro organismo consiente" (p. 155).

Antes he señalado que la solución del hilo de la voluntad es resultado de un empeño de la inteligencia, al que puede contribuir, entre otros elementos, la poesía. La poesía es más propia de las edades tempranas, en tanto que el conocimiento filosófico lo es de las edades maduras. En Parerga y paralipomena, I, escribe Schopenhauer: "En la juventud predomina la intuición; en la vejez, el pensar. Por eso la primera es el tiempo de la poesía; la segunda, más bien el de la filosofía" (1995, p. 54). Y Antonio Machado escribe en "Coplas mundanas", poema XCV de Soledades, galerías y otros poemas: Poeta ayer, hoy triste y pobre
filósofo trasnochado,
tengo en monedas de cobre
el oro de ayer cambiado.

(A. Machado, II, p. 490)

Esta cuarteta, que abre y cierra el poema, expone un motivo mucho más que ocasional: el del tránsito desde la edad de oro - juventud, poesía — a la de cobre madurez, filosofía-. El mito hesiódico de la edad de oro resuena aquí no como referencia a un pasado glorioso de la civilización, sino al tiempo personal de la juventud. El poema es de los añadidos en 1907 al primitivo núcleo de las Soledades de 1903: distaba mucho Machado entonces de ser aún viejo; pero su voz había ya iniciado un camino que lo conduciría lejos de los primitivos laberintos simbolistas. Bastantes años después, en un poema incorporado más tarde a los que constituyeron la primera edición de Campos de Castilla (1912), volvería sobre ello. Se trata de la composición CXLI de su obra, perteneciente a la serie "Homenajes" y dedicada a Xavier Valcarce:

Valcarce, dulce amigo, si tuviera

la voz que tuve antaño, cantaría

el intermedio de tu primavera

-porque aprendiz he sido de ruiseñor un día-,

[...]

Mas hoy... ¿será porque el enigma grave

me tentó en la desierta galería,

y abrí con una diminuta llave

el ventanal del fondo que da a la mar sombría?

¿Será porque se ha ido

quien asentó mis pasos en la tierra,

y en este nuevo ejido

sin rubia mies, la soledad me aterra?

El autor ha identificado implícitamente la tarea del poeta con el canto del ruiseñor, símbolo bien conocido de la poesía modernista. Los interrogantes repro- 
ducidos, cernidos sobre el apagamiento apenas expreso de su voz, contienen los dos posibles motivos de éste: el acceso a una verdad metafísica, inicialmente enigmática, y la soledad sobrevenida tras la muerte de la "rubia mies" (su esposa Leonor). Sea por lo uno o por lo otro, el poema prosigue con una taxativa afirmación análoga a la de la anterior contraposición entre poesía -canto- y meditación trascendente — ahora rezo-:

No sé, Valcarce, mas cantar no puedo;

se ha dormido la voz en mi garganta,

y tiene el corazón un salmo quedo.

Ya sólo reza el corazón, no canta.

(A. Machado, II, pp. 588-9).

\section{Nirvana búdico, renunciación cristiana: el océano de las nadas}

La condición de la filosofía schopenhaueriana supuso, según se ha dicho, más que una transformación de los paradigmas filosóficos occidentales por el procedimiento de su desarrollo radical, una verdadera suplantación de los mismos. Los sustituyen los propios de la filosofía hindú, principalmente del budismo sánscrito, y también del brahmanismo, cuyos principios esenciales son respetados por el budismo.

Schopenhauer había especificado que, en los cincuenta años anteriores, hubo tres elementos muy influyentes en el pensamiento de su tiempo: "la filosofía de Kant; los progresos incomparables de todas las ciencias naturales, que hacen que en la vida de la humanidad las épocas anteriores no sean ya, frente a la nuestra, sino una infancia; $y$, en fin, el conocimiento de la literatura sánscrita, del brahmanismo y del budismo, las dos religiones más antiguas y más difundidas que ha tenido la humanidad, es decir, las primeras de todas en el sentido del tiempo y del espacio: ellas fueron incluso la religión primitiva y nacional de nuestra propia raza, asiática como ya se sabe, que vuelve a tener ahora noticias de ellas en su patria extraña" (Schopenhauer, 1971, p. 18). Atenidos a la almendra nuclear del budismo, así pueden formularse los rasgos con que básicamente concuerda Schopenhauer: vida es aflicción, causada por las propias ansias de vida, que se sobreviven a sí mismas en una suerte de circularidad existencial; la única manera de extinguir esa aflicción es actuar sobre la sed de existir, no intentando saciarla - pues ello no hace sino prorrogar el sufrimiento de una vida reanudándose de continuo - sino apagarla mediante la negación, hasta llegar a un punto de cesación del dolor y de la misma capacidad de renacimiento perpetuo - la transmigración - por agotamiento de la actividad fenoménica. El estado en que dicha cesación se produce, y por ende la eliminación del dolor de vivir, es el nirvana, donde el ser concluye identificado con el todo, perdiéndose de este modo la propia individualidad sustentante del ser.

Pero más atrás he señalado que el corte entre el cristianismo y las teorías filosóficas schopenhauerianas, tan impregnadas de las doctrinas hindúes, es "no 
total". En efecto, la filosofía de Schopenhauer coincide con algunos de los elementos cristianos en no pocas cosas. La negación schopenhaueriana de la voluntad de vivir es semejante al ideal de perfección cristiano, que se alcanza a través de la purgatio que rehúsa los dones vitales, propia de los ascetas (como también de la filosofía nirvánica budista), y que, según hemos visto, encuentra en la figura de los monjes y anacoretas un ejemplo supremo. A esa instancia nirvánica —extinción de los deseos- se llega ejercitando la mirada en el desprendimiento de todo anhelo, según escribe en El legado manuscrito, I: "Una mirada que vea ponerse el sol desde una cárcel igual que desde un palacio. Esa mirada es lo que hay que desear, y nada más" (Schopenhauer, 1995, p. 20). La doctrina ascética cristiana, que derivaría por acomodación hipócrita en un clericalismo repulsivo, se perfecciona en la obra de los místicos, con sus propuestas de amor, resignación, pobreza, impasibilidad, abandono a la intuición divina. Esta negación de la voluntad de vivir, occidental y cristiana, tiene su correspondencia en la más desarrollada cultura de la nada entre los hindúes, que Schopenhauer se complace en glosar y describir. Y así, pondera el carácter fundamental, no arbitrario ni casual, del hecho de que muchos millones de seres lleven varios milenios practicando un modelo moral de pobreza voluntaria, soledad escogida, mortificación, autoaniquilamiento. El parentesco cntre el canon ético de plenitud cristiana y el budista fue intensamente destacado por Schopenhauer:

Pero a ello se añade la asombrosa coincidencia que uno detecta al comparar la vida de un penitente o un santo cristiano y la de uno de la India. En medio de unos dogmas, unas costumbres y un entorno radicalmente diferentes, tanto el anhelo como la vida interior de ambos son enteramente idénticos, al igual que lo es el espíritu de las prescripciones; así, por ejemplo, Tauler habla de la pobreza absoluta que uno debe buscar, la cual no consiste sino en desistir y privarse de cuanto pueda proporcionar un consuelo o un goce mundanos, puesto que todo eso suministra nuevo alimento a esa voluntad cuya total extinción se procura, y nos encontramos con su equivalente hindú en las prescripciones de Fo (o Buda) al saniassi, el cual debe carecer tanto de casa como de cualquier otro patrimonio, llegándosele a recomendar que no se acueste a menudo bajo el mismo árbol, a fin de no contraer preferencia o inclinación algunas hacia él. Los mismos rasgos vienen a expresar integramente el espiritu de las prescripciones. Mas tan enorme coincidencia en épocas y pueblos tan diversos constituye una prueba fáctica de que aquí no impera, como sostiene gustosamente la simpleza del optimismo, un desatino o una excentricidad del espíritu, sino que se expresa un aspecto esencial de la naturaleza humana, que sólo a causa de su eminencia y sublimidad se presenta en contadas ocasiones (Schopenhauer, 1993, pp. 174-5).

Es así como el cristianismo, que se presenta enfrentado al budismo y a la filosofía schopenhaueriana, tiene sin embargo determinadas expresiones extremas, por radicalización de algunas de sus propuestas ascéticas de mejoramiento moral, que conectan con ambos. La nada como punto al que propende el ejercicio de perfección - una suerte de nihilismo proyectivo- es centro donde convergen las formas ascético-místicas del cristianismo y las propias del nirvana búdico, unas y 
otras en pos de la desposesión o negación de los contenidos existenciales que puedan actuar de materia opaca que impide la disponibilidad. Referido a Miguel de Molinos, ha escrito José Ángel Valente lo que sigue:

El alma que ha optado por tan radical salida ha de descondicionarse de cuanto pueda poner en ella obstáculo a la manifestación de lo divino o de lo uno, a la suprema epifanía de la unidad simple. Por eso la vía que lleva al alma a la entera salida de sí misma ha sido reiteradamente descrita en la tradición mística como un proceso de absoluta desposesión. Sólo en la desapropiación, en el desasimiento, en la pobreza, es posible la salida del espíritu, la radical salida de la noche oscura. La pobreza es el otro nombre de la vacuidad o del vacio o de la nada que ha de operar en su interior el alma para hacerse lugar de la iluminación. Como la salida prefigura la iluminación, sólo la pobreza prefigura la salida y la constituye. El místico es el que ha comprendido la absoluta dimensión de las palabras evangélicas: Bienaventurados los pobres de espíritu. De los muchos contenidos de la experiencia mística que hoy podríamos sentir, por carencia, próximos, quizá ninguno resulte más inmediato que la plenaria significación de la pobreza (o de lo que el budismo Zen ha llamado el estado de noobtención (Valente, 1983, pp. 78-9).

Esa concomitancia del cristianismo con el pensamiento hindú se produce respecto a la vida inteligente; mucho menos en el universo de los animales (Schopenhauer, 1971, pp. 182 ss.), pues si por tantos conceptos el cristianismo presenta una moral afín, aunque menos intensa, a la del brahmanismo y budismo, no sucede así en cuanto a la relación de hombres y animales, entre los que aquél mantiene una separación tajante. En virtud de un antropocentrismo jerárquico, el hombre occidental establece una suerte de "ley del embudo", vejatoria y cruel, en el trato con los restantes seres de la naturaleza, según se ha hecho notar al hablar de la compasión. A este particular puede añadirse que la bondad primigenia del cristianismo - cuya creencia central, la de un dios hecho hombre, procedería de la India y llegaría a Judea pasando por Egipto- se habría desnaturalizado en parte, según Schopenhauer, al caer en suelo judío, lo que produjo la desgraciada judaización occidental. Un proceso análogo de desnaturalización es el que suele generarse cuando la mente occidental, proclive a considerar la religión como el ámbito de un teísmo providencialista, quiere adoptar, o simplemente entender, los principios de la religión búdica ${ }^{13}$.

13 En el apartado "Sinología" de Sobre la voluntad en la naturaleza (Schopenhauer, 1979), al referirse a las religiones más importantes de China, el filósofo alude al eurocentrismo con que tales creencias son contempladas. Sorprende en ellas la vida armónica que llevan entre sí, aunque finalmente estén todas subordinadas al budismo, religión "a la que, tanto a causa de su interna excelencia y verdad, como por el predominante número de sus fieles, hay que considerar como la principal en la tierra" (p. 186). Respecto al citado eurocentrismo, señala Schopenhauer: "Los europeos que se ocupan en adquirir noticias acerca del estado religioso de China parten para ello, como es ordinario y lo han hecho antes, en análogas circunstancias, los griegos y romanos, del punto de contacto de aquéllas con sus propias creencias nativas. Y como quiera que, según su modo de pensar, el concepto de la religión se identifica con el de teísmo, o por lo menos han crecido tan juntos que no sabe separarlos, y como quiera, además, que antes de haberse obtenido exacto conocimiento del Asia se había difundido en Europa, para el fin del 
No deben apurarse mucho más allá las semejanzas entre filosofía schopenhaueriana (y budismo sánscrito) y cristianismo. El paraíso de la plenitud que propone el mito cristiano apunta a la inmortalidad, al contrario que en la adaptación schopenhaueriana del budismo. Aun si se niega racionalmente la trascendencia que se asocia con la existencia de Dios, la mentalidad cristiana entiende esto como un cercenamiento de las expectativas primeras. Un poeta del 27, Luis Cernuda, que había colocado su poema en prosa "Escrito en el agua" como cierre de la primera edición de Ocnos (1942), se atreve a plasmar el avance desde una concepción mendicante de eternidad ("Desde niño, tan lejos como vaya mi recuerdo, he buscado siempre lo que no cambia, he deseado la eternidad") a la taxativa y consciente renuncia a ella ("Fue un sueño más, porque Dios no existe"), desarrollando un camino de retorno a la oquedad metafísica que, al detenerse en lo fenoménico y regodearse, por tanto, en la representación, es disímil al que propugna el pesimismo schopenhaueriano: "el anhelo de Cernuda, en vez de ser una voluntad de extensión infinita, es un deseo de experimentar como eterno el limitado mundo fenoménico, de demorarse en el momento pasajero sin conciencia de su paso" (Silver, 1996, p. 147).

\section{El dolor de la consciencia}

En el pensamiento hindú, en fin, la compasión no queda acotada a los humanos, pues que todos padecemos el mismo dolor. Poblado por seres impelidos por una fuerza irracional, nuestro mundo es un circo donde cualquiera es victimario y víctima al mismo tiempo. Pero la capacidad de percibir ese dolor que a todos afecta es proporcional a la consciencia de cada quien. El serventesio inicial del poema de Rubén Darío "Lo fatal", cierre de Cantos de vida y esperanza (1905), establece una jerarquización entre las diversas formas de sensibilidad ante el dolor: la vida consciente en la cúspide de la pirámide, después el árbol, más abajo la piedra dura:

Dichoso el árbol que es apenas sensitivo, y más la piedra dura, porque ésa ya no siente, pues no hay dolor más grande que el dolor de ser vivo, ni mayor pesadumbre que la vida consciente.

Es éste un poema que puede leerse a la luz de Schopenhauer; pero, indudablemente también, a la del romántico Leopardi, uno de cuyos poemas lunares, el "Canto notturno di un pastore errante dell'Asia" (Leopardi, 1989, pp. 205-13), revela la distancia entre racionales e irracionales:

argumento consensu gentium, la falsa opinión de que todos los pueblos de la tierra reverencian a un solo Dios, o por lo menos a un Dios supremo y creador, y como se hallaron en un país en que vieron templos, sacerdotes, claustros en abundancia y usos religiosos en frecuente ejercicio, concluyeron, sobre la base de su prejuicio, que había que encontrar allí teísmo, si bien en forma extraña" (pp. 187-8). 
Se tu parlar sapessi, io chiederei:

dimmi: perché giacendo

a bell'agio, ozioso,

s'appaga ogni animale;

me, s'io giaccio in riposo, il tedio assale?

(vv. 128-32)

El sujeto supone que su rebaño encuentra serenidad en el sesteo placentero, en tanto que él sólo encuentra tedio. Y se imagina más feliz si fuera ave y sobrevolara la tierra; algo similar a lo que afirma Darío en "Lo fatal". Sin embargo, el poema de Leopardi acaba exponiendo la sospecha de que cualquier tipo de existencia es, sólo por eso, desgraciada, y el día del nacimiento, ya sea "dentro covile o cuna", es un funesto día:

forse in qual forma, in quale stato che sia, dentro covile o cuna, è funesto a chi nasce il dì natale.

(vv. 141-3)

No hay, según Rubén Darío, "mayor pesadumbre que la vida consciente", pues la melancolía que emana de la condición humana será mejor — más dolorosamente- percibida por el hombre de genio, aquel en que prepondera anormalmente la sensibilidad ("Aristoteles ait omnes ingeniosos melancholicos esse": es una cita de Cicerón que trae a colación, a este respecto, Schopenhauer). No es sólo en "Lo fatal" donde expone el poeta nicaragüense esta idea. Bastará recordar su soneto "A Phocás el campesino", incluido en el mismo libro, para ver reproducida idéntica consideración:

Phocás el campesino, hijo mío, que tienes, en apenas escasos meses de vida, tantos dolores en tus ojos que esperan tantos llantos por el fatal pensar que revelan tus sienes...

Tarda en venir a este dolor adonde vienes, a este mundo terrible en duelos y en espantos; duerme bajo los Ángeles, sueña bajo los Santos, que ya tendrás la Vida para que te envenenes...

Sueña, hijo mío, todavía, y cuando crezcas, perdóname el fatal don de darte la vida, que yo hubiera querido de azul y rosas frescas;

pues tú eres la crisálida de mi alma entristecida, $y$ te he de ver en medio del triunfo que merezcas renovando el fulgor de mi psique abolida.

El "Phocás el campesino" del soneto es su hijo Rubén Darío — primero habido con la humilde campesina Francisca Sánchez-, que moriría el mismo año en que aparece Cantos de vida y esperanza. El niño ejemplifica el dolor larvado, sólo 
apuntado en el "fatal pensar" que habría de aflorar cuando cobrara plenitud de razón. Frente a la vida envenenadora, inherentemente aflictiva, ángeles y santos representan las brumas de la inconsciencia. Los "delincuentes sin culpa" que son los niños para Schopenhauer, están precisamente condenados a vivir. Pío Baroja ha efectuado en diversas ocasiones reflexiones similares; repárese en la aseveración que hace Iturrioz, el tío del protagonista de El árbol de la ciencia, a Andrés Hurtado cuando éste quiere saber su opinión sobre el matrimonio de un "hombre artrítico, nervioso" —en realidad el propio Hurtado- y su novia, "débil y algo histérica": "yo pienso en el hijo; yo no creo, como Calderón, que el delito mayor del hombro sea el haber nacido. Esto me parece una tontería poética. El delito mayor del hombre es hacer nacer" (Baroja, 1983, p. 233); pues el dolor de quienes sí tienen culpa, precisamente por propagarlo, ha de ser arrastrado después por los que carecen de ella ${ }^{14}$. Esto explica que, en el poema reproducido, el autor solicite a su hijo perdón por el "fatal don de darte la vida".

Es éste un motivo recurrente en la poesía generacional. El propio Unamuno incluyó en su libro Poesías unas trémulas nanas ("Al niño enfermo") dirigidas a su hijo hidrocefálico Raimundo Jenaro (1896-1902), quien estuvo en el centro existencial de su honda crisis de 1897, de la que dejó testimonio en los cuadernillos escritos por esos años y editados mucho después de su muerte con el título de Diario intimo. En estos versos viene Unamuno a coincidir con el Rubén de Cantos de vida y esperanza en la idea del sueño como asilo del dolor y sucedáneo de la muerte, que es la protección definitiva contra el sufrimiento:

Duerme, flor de mi vida, duerme tranquilo, que es del dolor el sueño tu único asilo.

Duerme, mi pobre niño, goza sin duelo lo que te da la muerte como consuelo.

Como consuelo y prenda de su cariño, de que te quiere mucho, mi pobre niño.

Pronto vendrá con ansia de recogerte la que te quiere tanto, la dulce muerte.

14 En El mundo como voluntad y representación (libro IV, parágrafo 63) cita Schopenhauer los dos versos calderonianos de La vida es sueño a los que se refiere Iturrioz ("pues el delito mayor/del hombre es haber nacido"); un delito, señala el filósofo, que se castiga con la muerte. 


\section{Dormirás en sus brazos \\ el sueño eterno, y para ti, mi niño, no habrá ya invierno. \\ $[\ldots]$ \\ Morirás con la aurora, flor de la muerte; te rechaza la vida, ¡qué hermosa suerte! \\ El sueño que no acaba duerme tranquilo, que es del dolor la muerte tu único asilo.}

(Unamuno, 1, pp. 123-4)

Y, para no multiplicar los ejemplos, en De Fuerteventura a París incluye Unamuno un soneto al entierro, en el cementerio parisiense de Pantin, del niño Yago de Luna, donde reaparece el motivo antedicho:
A un hijo de españoles arropamos hoy en tierra francesa; el inocente se apagó --ifeliz él! - - sin que su mente se abriese al mundo en que muriendo vamos. [...] "Ante la vida cruel que le acechaba, mejor que se me muera" — nos decía su pobre padre...

(Unamuno, II, p. 340)

\section{Del dolor de la historia al dolor de la naturaleza}

Al fin, la lección de Schopenhauer combina la amargura y la pasividad. Ello no empece para que en los Parerga y paralipomena, I, en que se perciben notas templadamente epicúreas de Schopenhauer y se destensa el sistema radical de su filosofía tal como es expuesto en sus obras mayores, escriba: "Toda limitación proporciona felicidad. Cuanto más estrecho es nuestro círculo de visión, de acción o de roce, tanto más felices somos; y cuanto más amplio es, tanto más frecuentemente nos sentimos atormentados y angustiados" (Schopenhauer, 1995, p. 153). También en El árbol de la ciencia, de Baroja, aparece una invitación por parte de Iturrioz a la acción limitada, a la acotación del ámbito en que pudicra aplicarse la tarea reformadora: "ante la vida no hay más que dos soluciones prácticas para el hombre sereno: o la abstención y la contemplación indiferente de todo, o la acción limitándose a un círculo pequeño" (Baroja, 1983, p. 96). En línea con lo que habíamos expuesto atrás a propósito del avance del irracionalismo, y obviando lo margi- 
nal de la anterior observación schopenhaueriana si la contextualizamos en el conjunto de su obra, la falta de ambición de la hipotética actuación positiva supone una defensa tácita de lo establecido, o si se quiere una postura políticamente conservadora, por lo que tiene de justificación del inmovilismo de pueblos y colectividades. Y no porque Schopenhauer - como el personaje barojiano referido- crea que merece la pena conservar algo, sino, más bien, porque niega la idea del progreso humano: de ahí la inutilidad del esfuerzo. La neutralización del descontento ante las injusticias sociales significa la exoneración de cualquier tipo de responsabilidades históricas. Es así como resurge la concordancia entre Schopenhauer y quienes, desde la preterición de lo terrenal no por repudio de la fe, sino precisamente por fe en lo ultratelúrico, rechazan cualquier acción tendente a la mejora de la sociedad, pues que "el reino" no está en este mundo; y aun no limito la observación sólo a los auténticamente creyentes, sino a quienes entienden que la inmortalidad, incluso sin creer en ella salvo como ilusión reconfortadora de crédulos, es el único desideratum cuya consecución merecería la pena. Aludo, por ejemplo, a don Manuel, el cura unamuniano de San Manuel Bueno, mártir, en sus cambios de impresiones con el progresista Lázaro antes de la "conversión" de éste.

Creo que el centro de esta actitud, que sobrevuela la estricta obediencia schopenhaueriana, es la consideración de los males del hombre como entidades no históricas, sino constitutivas de su misma textura humana. Esta idea medular hace de la crisis noventayochista algo que trasciende, hasta donde no se ha ponderado quizás lo suficiente, lo específicamente "nacional". Cuando nos enfrentamos, por ejemplo, a las categorías novelescas - sea: nivolescas- de un autor como Unamuno, lo que nos sorprende es el carácter ucrónico de personajes y problemas. La condición problemática de los primeros no es debida sólo, ni siquiera fundamentalmente, a la precariedad del medio - como tampoco lo es, si bien algo más, en una novela tardofranquista como Tiempo de silencio, de Martín-Santos-, sino a su sustancia de hombres. El dolor es inherente al hombre, y una supuesta república perfecta - la de Platón, la de Thomas More, la de Campanella - no haría sino eliminar las fallas del sistema por donde desaguan, como en un proceso biológico de somatización de determinados males del espíritu, los dolores de la existencia. Ninguna suerte más trágica que la de un utopista que hubiera logrado construir y habitar la ciudad ideal. Así que esos personajes de las nivolas y dramas de Unamuno carecen de cuajo histórico, y en ellos no cuentan decisivamente las contingencias temporales.

Schopenhauerianamente, es inútil enfrentarse a los dolores que la vida plantea, porque subsistirían en cualquier otra coyuntura histórica, de un lado; y, de otro, porque el carácter natural e intrínseco de los mismos hace que proponerse su extinción sea una lucha contra naturam; esto es, contra la naturaleza misma de quienes padecen esos dolores. El corolario moral es, como cabe apreciar, profundamente melancólico. Cosa distinta es que muchos de los héroes noventayochistas se resis- 
tan a dejarse engullir por lo que significaría la condena a la inacción, y propugnen la intervención regeneracionista, o, mucho más vertiginosamente, como ciertos personajes barojianos, la actuación en el vacío - el Paradox de Aventuras, inventos y mixtificiones de Silvestre Paradox - o la acción por la acción. Son seres a los que podría aplicárseles el preciso axioma de Leopardi (Pensieri, XXXI) que recoge Savater para referirse a la esencialidad del pesimismo schopenhaueriano: "Ios hombres son miserables por necesidad y están resueltos a creerse miserables por accidente" (Savater, 1992, p. 520). Como he afirmado a propósito de J. Martínez Ruiz y La voluntad, si unas veces "el escritor parece creer que el mal es histórico y circunstancial, y por ello apelaba, por boca de Yuste, a la acción revolucionaria, en otras ocasiones el mismo Yuste se ancla en una conformidad que Antonio Azorín considera suicida; ahí la defensa que el maestro hace de la 'rebeldía pasiva' tolstoiana para acceder al reinado de la justicia, aduciendo los ejemplos pacifistas de Buda, Sócrates o Jesús. Y aún más: en el fondo Yuste descree de toda posibilidad de mejora, ya sea a través de la revolución ya de la pasividad, entendiendo que el mal es inamovible, constitutivo esencial del ser" (Prieto de Paula, 1993, p. 16). El personaje terminal, erguido en su desesperanza, es aquel que ha concluido el camino que lleva desde el dolor de la historia hasta el dolor de la naturaleza.

El estado espiritual de quienes han conformado su vida de acuerdo con la incertidumbre del ser, o con la certidumbre de la nada, bascula entre los estertores agónicos y el bostezo universal, recorriendo todas las irisaciones del sentimiento humano desposeído de la felicidad. En los escritores españoles de comienzos del novecientos no podría, en casi ningún caso, discriminarse qué influjos provienen de la lectura schopenhaueriana, cuáles de la de otros filósofos pesimistas, cuáles, cn fin, de la de ciertos simbolistas, o, más atrás, románticos, aquejados todos de la implenitud del mundo, ya sea en la vertiente de la desesperación, ya en la de la desesperanza. Varias veces ha señalado Schopenhauer que, si la penuria engendra dolor, la riqueza produce aburrimiento. Los nómadas, pobres entre los pobres, van de un lugar a otro para escapar de la aflicción generada por la miseria, y los "turistas" hacen lo propio para huir del hastío producido por la riqueza: unos enlazan, así, con los otros. En los Parerga y paralipomena aparecen incitaciones a la aurea mediocritas, que sólo atempera el suplicio de vivir al actuar como punto equidistante de la desdicha de la miseria y del aburrimiento de la abundancia. Según este modelo, bien conocido ya en la literatura de los siglos XVI y XVII en sus formas más o menos radicales — de Fray Luis a Quevedo, pasando por Medrano o el capitán Andrada-, el hombre eximio buscará una vida sin estorbos, sin preocupaciones, sin enojosas compañías. Los dos extremos a que me acabo de referir son igualmente, en sus diversas denominaciones o ramificaciones, emanaciones de esa implenitud que digo: registros del humor negro de los hombres, variaciones de la melancolía. Tal como afirma el gran Leopardi, "L'assenza di ogni special sentimento di male $\mathrm{e}$ di bene, ch'è lo stato più ordinario della vita, non è né indifferente, né bene, né piacere, ma dolore e male. [...] Quando l'uomo non ha sentimento di alcun 
bene o male particolare, sente in generale l'infelicità nativa dell'uomo, e questo è quel sentimento nativo che si chiama noia" (Zibaldone, 4498, 4 de mayo de 1829). Dicha noia, que hacemos corresponder con la ausencia de expectativas de felicidad, es el sustrato de la existencia humana, esa que el pesimista de Recanati llamó, en la línea de su congénere en el pesimismo Schopenhauer, l'infelicità nativa dell'uomo. Pero las analogías entre Leopardi y Schopenhauer, a los que Fernando Savater considera extrañamente similares, no van mucho más allá. Para el italiano, la orfandad del hombre tiene que ver con la nostalgia romántica del ideal helénico, constituido por la claridad y el orden paradisíacos de los que el hombre contemporáneo se siente desterrado. En el caso de Schopenhauer no existe esa retrospección psíquica que pone el anhelo en un mundo definitivamente agotado, como si la luz de una estrella muerta llegara hasta él por los espacios siderales para provocar su melancolía:

Ce pessimisme n'a rien à voir non plus avec l'affliction culturclle d'un Leopardi, nostalgique de la belle naïveté perdue depuis les Grecs. Schopenhauer ignore le mythe humaniste de l'Hellade et n'a jamais eu de larmes pour la mort des anciens dieux; ni avec le platonisme impuissant et rageur d'un Flaubert; ni avec les soupirs de Renan, pris d'un vertige sceptique devant les productions de son propre historicisme. La découverte que Schopenhauer a faite avant de la transmettre à Nietzsche est que le monde n'est justement pas une illusion, mème si nous ne le voyons pas dans sa réalité. Il n'y aura jamais pour l'homme que la minute actuelle, les choses qui l'entourent, les êtres qui conspirent contre lui, son tourment intérieur (Henry, 1989, p. 40).

Y termino. Quizás sea exagerado atribuir a Schopenhauer efectos que, sin él, hubieran también formado parte de la atmósfera literaria de la época. Alguna vez se ha distinguido entre lo que se aprende en el filósofo y lo que se va a buscar en él, como si se deseara confirmar lo que ya se sabía (Fox, 1989). Por lo demás, determinados resortes expresivos, que a veces han sido imputados a su influjo, tienen una causa más compleja. Pondré, como ejemplo, el de la literatura aforística, visible en tantos autores, desde el Antonio Machado de los "Proverbios y cantares" a Eugenio d'Ors o José Bergamín. Pues si influye el aforismo schopenhaueriano, tal como se presenta, por ejemplo, en los Parerga y paralipomena, lo hace más el de Nictzsche, aparte de que existen otras muy varias influencias (tradición parenética medieval y barroca, conceptuosidad gracianesca, emblemática, jaikú...) que desembocan en el tono sentencioso y la quintaesencia filosófico-moral, a veces trufados de una imaginería que ya se vincula a la arbitrariedad tropológica de las vanguardias. Una futileza, al cabo. El que he aducido como ejemplo, lo mismo que otros, son sólo rasgos formales que no pueden ocultar la mayor importancia de una tarea cducadora, absolutamente subversiva, que abrió esa otra caja de Pandora de la que, esta vez, huiría también la esperanza. 


\section{BIBLIOGRAFÍA CITADA}

ABELLÁN, J. L. 1992. Historia crítica del pensamiento español, I, Barcelona, Círculo de Lectores ( $1^{\text {a }}$ ed.: Madrid, Espasa Calpe, 1979).

AZCÁRATE, G. de. 1877. El Self-Government y la monarquía doctrinaria, Madrid.

AZORÍN (pseud. de J. Martínez Ruiz). 1982. Obras selectas, Madrid, Biblioteca Nueva, $5^{a}$ ed.

BAROJA, P. 1974. Camino de perfección, Madrid, Caro Raggio.

BAROJA, P. 1983. El árbol de la ciencia, Madrid, Alianza (1ª ed.: 1967).

CERNUDA, L. 1974. La realidad y el deseo, Madrid-México, FCE ( $2^{2}$ reimpr. de la $4^{a}$ ed. en FCE, 1964).

FOX, E. I. 1989. Ideología y política en las letras de fin de siglo, Madrid, Espasa Calpe.

GARCÍA CAMARERO, E. y E. 1970. La polémica de la ciencia española, Madrid, Alianza.

GONZÁlEZ NORIEGA, S. 1979. Prólogo a A. Schopenhauer, Sobre la voluntad en la naturaleza, cit. infra, pp. 7-20.

HENRY. A. (ed.). 1989. Schopenhauer et la création littéraire en Europe, París, Méridiens Klincksieck.

JESCHKE, H. 1934. Die Generation von 1898 in Spanien, Halle, Niemeyer. Trad. esp.: La generación de 1898 en España, Madrid, Editora Nacional, 1954 (1 ${ }^{\text {a }}$ ed.: Santiago de Chile, Universidad, 1946).

KRAUSE, A. 1948. Azorin, the little philosopher, Berkeley, University of California. Trad. csp.: Azorín, el pequeño filósofo, Madrid, Espasa Calpe, 1955.

LEOPARDI, G. 1989. Canti, Milán, Garzanti (1ª ed.: 1975).

MACEIRAS, M. 1985. Schopenhauer y Kierkegaard: sentimiento y pasión, Madrid, Cincel.

MACHADO, A. 1988, 1989. Poesía y prosa, 4 vols. (I, III y IV: 1988; II: 1989), edición crítica de Oreste Macrì, Madrid, Espasa Calpe / Fundación Antonio Machado.

MASSON DE MORVILLIERS, N. 1782. "Espagne", en AA.VV., Géographie moderne, I, pp. 554-568; en Encyclopédie méthodique, París.

PRIETO DE PAULA, Á. L. 1991. "Desde Leopardi a los escritores españoles de fin de siglo: hacia una caracterización del "mal de la ticrra", Quaderni di 
Filologia e Lingue Romanze. Ricerche svolte nell'Università di Macerata, $3^{\mathrm{a}}$ serie, 6, pp. 63-80.

PRIETO DE PAULA, Á. L. 1993. "La novela de J. Martínez Ruiz: voluntad, ataraxia, abulia", Ínsula, 556, pp. 15-16.

RÁBADE, A. I. 1989. Introducción a A. Schopenhauer, Antología, cit. infra, pp. 518.

ROMANO GARCÍA, V. 1970. Prólogo a A. Schopenhauer, Los dos problemas fundamentales en la ética, I, cit. infra, pp. 9-36.

SAVATER, F. 1992. "Schopenhauer", en V. Camps, ed., Historia de la ética, II, Barcelona, Crítica.

SCHOPENHAUER, A. 1928. El mundo como voluntad y representación, trad. de E. Ovejero y Mauri, Madrid, Aguilar.

SCHOPENHAUER, A. 1970, 1971. Los dos problemas fundamentales de la ética, 2 vols. (I: Sobre el libre albedrio, 1970; II: El fundamento de la moral, 1971), trad. y pról. de V. Romano García, Buenos Aires, Aguilar (1ª ed.: 1965).

SCHOPENHAUER, A. 1979. Sobre la voluntad en la naturaleza, trad. de M. de Unamuno, pról. de S. González Noriega, Madrid, Alianza (1ª ed.: 1970).

SCHOPENHAUER, A. 1989. Antología, ed. y trad. de A. I. Rábade, Barcelona, Península.

SCHOPENHAUER, A. 1993. Metafísica de las costumbres, trad. de R. Rodríguez Aramayo, Madrid, Debate / CSIC.

SCHOPENHAUER, A. 1995. Parábolas, aforismos y comparaciones, ed. y trad. de A. Sánchez Pascual, Barcelona, Edhasa.

SILVER, Ph. W. 1996. Ruina y restitución: reinterpretación del Romanticismo en España, Madrid, Vanderbilt University Press / Cátedra.

SOBEJANO. G. 1967. Nietzsche en España, Madrid, Gredos.

UNAMUNO, M. de. 1987, 1988, 1989. Poesia completa, 4 vols. (I y II: 1987; III: 1988; IV: 1989), Madrid, Alianza.

VALENTE, J. Á. 1983. La piedra y el centro, Madrid, Taurus. 